Principal Dimensions, Scantuings, \&cc.

Iron Work.

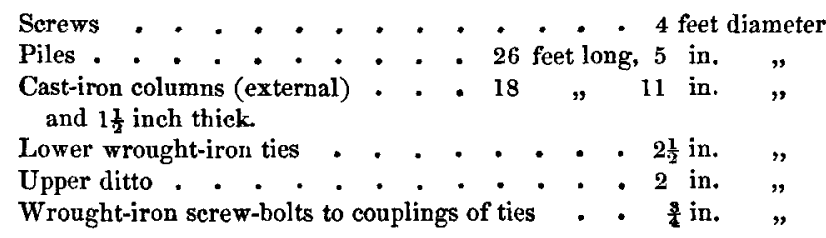

\title{
Timber Work.
}

External columns, 30 feet long, 12 inches square at the bottom and

$10 \frac{1}{2}$ inches at top.

Inches. Inches.

Half timber horizontal braces . . . . . . . $12 \times 4 \frac{1}{2}$

Upper whole ditto . . . . . . . . . . $10 \times 10$

Lower ditto . . . . . . . . . . . . $11 \times 10$

Raking braces . . . . . . . . . . $10 \times 10$

Joiners' Work.

Lantern curb . . . - . . . . . - . $12 \times 9$

Oak cill to ditto . . . . . . . . . . . . $12 \times 6$

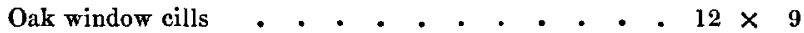

Oak door cill . . . . . . . . . . . . . $12 \times 9$

Door posts . . . . . . . . . . . . $6 \times 5$

Jamb linings to door . . . . . . . . $2 \frac{3}{4}$ thick.

Outside boarding to sides of dwelling . . . . . 2 "

Inside ditto - . - . - . - . . . . - $1 \frac{1}{2}$ ",

Pilaster boards . . . . . . . . . . . 2 "

Boarding to lower store - . . . . . . . 2 "

Ditto to lead flat . . . . . . . . . 2 "

Mr. Wilkins stated, in answer to questions from the President, that he had seen the Edystone and the Maplin Sand Lighthouses during severe gales of wind; that, as might be conceived from the nature of the construction, the latter building was more affected than the former by the striking of heavy seas : the motion appeared to be more like torsion than simple vibration, which he attributed to the waves striking the ladder and its projecting stage, and thus tending to twist the upper part. Still the motion was not such as would cause injury to the building.

Mr. Walker, President, pointed out two diagonal braces, extending downward from the end of the ladder stage to the piles on either side; these had been introduced in order to counteract the twisting described by Mr. Wilkins. In constructions of this nature, it was of importance to oppose as little resistance as possible to the waves, especially in the upper part of the building; a system of 
bracing had therefore been adopted, which consisted principally of two series of continuous circular horizontal ties between the piles, at the several heights of 6 feet and 15 feet above low-water mark of spring tides. From the external ring of piles, two sets of diagonal stays extended to the centre pillar, forming strong triangular trusses, in the direction of each pile, and two sets of horizontal stays stretched between the piles and the centre pillar, at the levels of the circular bands. The amount of direct vibration was very small, and he did not conceive that the twisting motion which had been described, was sufficient to warrant the introduction of diagonal braces between the main piles, which would materially augment the surface upon which the waves would act.

Mr. Vignoles directed the attention of the meeting to the system of diagonal bracing between the piles, which had been adopted at the Fleetwood on Wyre Lighthouse. He apprehended, that as the principal force of the waves would be exerted against that part of the structure which was above the level of high water, the diagonal braces extending between the upper part of the piles and the level of low water, were preferable to the horizontal continuous bands of the Maplin Sand Lighthouse, although they were aided by the system of radiating central truss braces which it possessed; he conceived that both buildings were strong enough for the purpose for which they were constructed; but he preferred the mode of bracing adopted in the Port Fleetwood house, the vibration of which he knew to be very small, although it was situated in an exposed position, where the rise of tide was 30 feet.

Mr. Donkin observed, that there could not exist a doubt of the introduction of diagonal braces rendering the building stronger; how far they were necessary, or might be prejudicial, in offering additional resistance to the passage of the waves, should be well examined, before adopting them. He considered the position of the suspended ladder decidedly objectionable, as any torsion, caused by the waves striking it, must tend to dislocate the fibre of the material of the piles, and to fracture them.

Mr. FAREY believed the construction of the Maplin Sand Lighthouse to be better adapted than that of the Fleetwood Lighthouse, for resisting the direct action of waves; but the diagonal bracing of the latter enabled it to withstand torsion better than the hoop bracing of the former. He inquired, why the lower part of the light-keeper's house was made conical? He apprehended that it would receive a heavier blow from a wave than if it had been flat.

Mr. Walker, President, replied, that the main body of the waves seldom, or never, rose so high as the bottom of the house, 
and that the conical form allowed the air and spray to rise up and be guided off, without affecting the building, as it would have done, if the bottom had been flat.

With regard to the torsion, that had only been felt at first, when the ladder extended too low down, and received a constant succession of blows from every wave, which naturally communicated a vibration to the whole structure: the ladder was now shortened, and nothing of the kind was felt, indeed the waves scarcely, even in the roughest weather, struck the suspension stage, or the boat. He preferred the continuous horizontal bracing, which bound all the piles firmly together like the staves of a barrel, and from observations he had made, he believed the amount of vibration to be greater in the Port Fleetwood Lighthouse, than in that at the Maplin Sand.

In answer to a question from Mr. G. H. Palmer, the President said, that at present (four years after the construction of the building) there was not the slightest indication of change in the condition of the cast-iron from its contact with the salt water.*

Professor Brande was unable to adduce any additional evidence on the observed facts connected with the change suffered by castiron, when exposed to the action of salt water, or in mines and in various other positions. From experiments which he had made, he was led to believe, that many of the appearances observed in the changes of cast-iron, arose rather from a peculiar mechanical combination of the molecules, than from a difference in the chemical constitution of the metal; no difference could be detected by analysis in the metal which had undergone change and that which had not.

It should be remarked, that the contact of two metals was not essential to cause galvanic action; a film of oxide upon the surface of the body of metal formed a very active galvanic pile: hence arose the necessity of preventing oxidation, by proper paint, or varnish, before using cast-iron in exposed situations.

Mr. FAREY observed, that in the early engines constructed by Woolf, in Cornwall, in which the packing segments were of gunmetal, and the body of the piston was of cast-iron, wherever the two metals were in contact, the iron was turned to plumbago; this had been particularly observed where high-pressure steam was used. It might be a question whether the temperature of the steam, and the quantity of mineral water carried over with it, by the large amount of priming of the engines in that day, had not materially contributed to produce the effect.

* In 1848, after ten years' immersion, neither the cast nor the wrought-iron appear to be at all affected by exposure, or by the action of the salt water. 
Mr. P. TAYLor believed, that the temperature of the steam had not any connexion with the subject. In the metallic packing of steam pistons of low-pressure marine engines, which he had constantly under repair at Marseilles, he found, that wherever the wedge pieces were of gun-metal, the backs of the cast-iron segments were converted into plumbago, while those surfaces of cast-iron which were ground together and worked against each other, remained unchanged; the same might be said of the rubbing surfaces of cast-iron against gun-metal ; it appeared, therefore, that the formation of an oxide was necessary to commence the change. $\mathrm{He}$ repudiated the use of cast-iron in situations where these changes were to be apprehended; he would employ wrought-iron, as although that did become oxidized, it retained its relative strength to the last, whereas cast-iron, when changed into plumbago, retained its bulk, but lost nearly all power of cohesion.

Mr. J. TAYLOR said, that in Cornwall, the cast-iron pump-trees exposed to the action of mine water, were very speedily destroyed; and even although they were $1 \frac{1}{2}$ inch thick, they could be cut to pieces with a knife, when first taken out of the pit. The air-pump buckets of steam-engines, in which the body was of cast-iron and the valves of gun-metal, formed the most perfect kind of galvanic apparatus; they should be made entirely of gun-metal.

In manufactories of vinegar and pyroligneous acid the decay of cast-iron was very rapid.

Mr. GLY N attributed, in a great degree, the rapid decay of cast-iron in coal mines, to the presence of sulphuric acid evolved from the pyrites.

Mr. P. Taylor agreed with Mr. Glynn; even copper pipes were rapidly destroyed in the bilge water of vessels, which always contained much sulphuretted hydrogen. He recommended the use of stout lead pipes in such situations, as they would be found much more durable.

Mr. Davison had found it necessary to substitute gun-metal gratings for the cast-iron ones, at Messrs. Hanbury's Brewery, as although they were $\frac{3}{4}$ inch thick, they had been entirely destroyed in four years.

Mr. Warker, President, mentioned incidentally a lighthouse constructing by Messrs. Gordon and Co., at Deptford, under his directions, for the Point of Ayr. The lantern for it would be cast from a gun which had been raised from the wreck of the Royal George. 